\title{
Microbes Population and Soil Respiration Under The Kemenyan (Styrax spp) Stand Rhizosphere
}

\author{
Deni Elfiati ${ }^{1}$, Arida Susilowati ${ }^{1}$, Nurhidayah $^{1}$, and \\ Henti Hendalastuti Rachmat ${ }^{2}$ \\ ${ }^{1}$ Faculty of Forestry, Universitas Sumatera Utara. Jl. Tri Dharma Ujung No 1, Kampus USU Medan \\ 20155. North Sumatra Indonesia \\ ${ }^{2}$ Forest Research, Development and Inovation Agency. Ministry of Environment and Forestry. Jln \\ Raya Gunung Batu. Bogor, West Java
}

\section{Abstract}

The rhizosphere defined as zone surrounds the root that it physical, chemical, and biological character directly influenced by root activities. The rhizosphere is characterized by high microbiological activities compared to bulk soil and affected the plant performance. The objectives of this research were to determine soil respiration and

Corresponding Author: Deni Elfiati

denielfiati@yahoo.com

Received: 19 February 2019

Accepted: 5 March 2019

Published: 16 April 2019

Publishing services provided by Knowledge E

(c) Deni Elfiati et al. This article is distributed under the terms of the Creative Commons

Attribution License, which permits unrestricted use and redistribution provided that the original author and source are credited.

Selection and Peer-review under the responsibility of the ICBSA Conference Committee. total population of soil microbes, including fungi and bacteria, phosphate solubilizing microbes, and organic matter decomposer microbes. Soil samples were collected from rhizosphere zone $(0-20 \mathrm{~cm})$ of kemenyan bunga, kemenyan durame, kemenyan batak and kemenyan minyak in Pardomuan village, Sitellu Urang Julu-Pakpak Bharat, North Sumatera. Microbial population was calculated using plate count method and soil respiration measured using jar methods. The result showed that the highest fungi and bacterial population were found under kemenyan durame rhizosphere those were 13.4 $\times 10^{7}$ and $15.7 \times 10^{7} \mathrm{CFU} \mathrm{mL}^{-1}$. The highest phosphate solubilizing microbes population $\left(96.8 \times 10^{4} \mathrm{CFU} \mathrm{mL}^{-1}\right)$ was also found in kemenyan jurame rhizosphere. The highest organic matter decomposer microbe found in kemenyan minyak rhizosphere those were $25.1 \times 10^{4}$ (fungi) and $73.2 \times 10^{4} \mathrm{CFU} \mathrm{mL}^{-1}$ (bacteria). The highest respiration (3.23 $\mathrm{mg} \mathrm{CO} 2100 \mathrm{~g}^{-1} \mathrm{day}^{-1}$ ) was also found in kemenyan jurame rhizosphere.

Keywords: bacteria, fungi, kemenyan, respiration, rhizosphere

\section{Introduction}

Soil was one of various factors that influence plant growth. Soil is a habitat for various types of microbes with various numbers and types. The presence of microbes in the soil plays an active role in fertilizing the soil, especially the soil under plant stands. Microbes in the soil consist of fungi, bacteria and actinomycetes. Each microbe has its own function in carrying out various important processes related to life. Microbes are 
doing various metabolic processes which are generally called biological activities [1, 2]. Microbes are responsible for decomposition organic matter and nutrient recycling.

Decomposer microbes are microbes which decompose fibers, lignin, and organic compounds from the residue of dead plants and animals. Decomposer microbes consists of the genus Trichoderma, Aspergillus, Penicillium, Pseudomonas, Cellulomonas and Streptomyces. Decomposer fungi generally have a better ability than bacteria in decomposing plant residu [3, 4]. Phosphate solubilizing microbes are microbes that play a role in helping the availability of phosphorus nutrients in the soil. In acid soils phosphorus bound to form aluminum phosphate and iron phosphate, whereas in the alkaline soil phosphorus bound forms insoluble calcium phosphate. The existence of phosphate solubilizing microbes plays a great role to make phosphate nutrient to be available for plant. In general, phosphate solubilizing microbes consist of Pseudomonas, Bacillus, Enterobacter, Penicillium and Aspergillus [5-9].

Kemenyan (Styrax spp) is one of the endemic plants in North Sumatra. Kemenyan can grow in wide range of habitats from lowlands to mountain forests up to 1600 meters above sea level [10]. Many studies on kemenyan have been conducted mostly those related to the species itself and its surrounding habitats, so it is necessary to study the existence of supporting activities such as the rhizosphere area. Rhizosphere is an area that is strongly affected by plant roots. Both plant and also microbes has a complex beneficial relationship. The existence of microbes in the soil is influenced by the quality of the vegetation grows on it while the activity of microorganisms will affect plant growth which ultimately determines the productivity of the land [3].

The purpose of the study was to calculate the total population of soil microbes, the population of phosphate solubilizing microbes, decomposer microbes and to calculate soil respiration.

\section{Material and Methods}

\subsection{Study site and sampling procedure}

This study was conducted at Pardomuan Village, Sitellu Urang Julu District Pakpak Bharat, North Sumatra. Soil samples were taken systematically at a depth of 0-20 $\mathrm{cm}$ around rhizosphere area of kemenyan bunga (Styrax sumatrana), kemenyan batak (Styrax benzoin evar. liferum), kemenyan minyak (Styrax tonkinennsis) and kemenyan durame (Styrax benzoin DRYAND) with three replication for each of kemenyan species. 
The samples were transferred into plastic bags and stored in ice box for transportation from the field to the laboratory and placed in a chilled room at $4-16{ }^{\circ} \mathrm{C}$ prior to analysis.

\subsection{Soil analysis}

Soil chemical properties were analyzed using soil $\mathrm{pH}$ by glass electrode method, organic $C$ with Walkley and Black method, $P$ available with Bray 2 method and cation exchange capacity by washing method with ammonium acetate [11]. Analysis was done at the Palm Oil Research Center North Sumatra.

\subsection{Measurement on microbial population and soil respiration}

The enumeration was conducted by plate counting technique from a series of dilution of each sample. Ten $\mathrm{g}$ of fresh soil was put into Erlenmeyer containing $90 \mathrm{~mL}$ of physiological solution ( $8.5 \mathrm{~g} \mathrm{NaCl}$ in $1 \mathrm{~L}$ distilled water) then shaken for $30 \mathrm{~min}$. One $\mathrm{mL}$ of pure culture was put into a $10 \mathrm{~mL}$ test tubes containing $9 \mathrm{~mL}$ of physiological solution (resulting in 100 times or $10^{-2}$ dilution,). It was shaken for one minutes and one $\mathrm{mL}$ of $10^{-2}$ dilution was taken for dilution of $10^{-2}$. Dilution process was continued until the dilution $10^{-8}$ was reached. For the bacteria, one $\mathrm{mL}$ of the $10^{-6}, 10^{-7}$, and $10^{-8}$ diluted solution was added with $10 \mathrm{~mL}$ of nutrient agar at $50^{\circ} \mathrm{C}$, then the culture was incubated for three days. For the fungi, decomposer microbes and phosphate solubilizing microbes, one $\mathrm{mL}$ of the $10^{-3}, 10^{-4}$, and $10^{-5}$ dilluted solution was added with $10 \mathrm{~mL}$ of nutrient agar at $50^{\circ} \mathrm{C}$, then incubated for three days. After incubation, the number of microbes was counted using quebec colony counter [12]. The number of microbes was calculated using Equation (1).

$$
\sum \text { colony } \mathrm{mL}^{-1}=\sum \text { colonies } \mathrm{x} \text { dilution factor }
$$

Soil respiration was measured with Jar method adapted from [12]. Fresh samples of $100 \mathrm{~g}, 5 \mathrm{~mL}$ of $0.2 \mathrm{~N}$ potassium hydroxide $(\mathrm{KOH})$, and $10 \mathrm{~mL}$ of water were incubated in $1000 \mathrm{~mL}$ vial for two weeks at $28-30^{\circ} \mathrm{C}$. At the end of the incubation period, two drops of phenolptalein was added into $\mathrm{KOH}$ beaker until a red solution is formed. $\mathrm{HCl}$ was added into the red solution until the red color disappears and at that point, the volume of $\mathrm{HCl}$ used in the titration was recorded. Afterwards, two drops of metyl orange was added into the solution until yellow color is formed. The solution, then was re-titrated with $\mathrm{HCl}$ to form pink color and the required $\mathrm{HCl}$ volume was recorded. A control vial with no soil was included in the incubation to correct for the $\mathrm{CO}_{2}$ in the jar at the initiation of 
the incubation. The amount of respiration ( $\mathrm{R}$ ) (in $\mathrm{mg} \mathrm{CO}_{2} 100 \mathrm{~g}^{-1}$ day $^{-1}$ ) was calculated using Equation (2).

$$
\mathrm{R}=\frac{(a-b) \times t \times 120}{n}
$$

Where $a$ is the volume of $\mathrm{HCl}$ used for titration $(\mathrm{mL}) ; b$ is the volume of $\mathrm{HCl}$ used for; titration of the blank/control $(\mathrm{mL}) ; t$ is the normality of $\mathrm{HCl} ; n$ is the incubation time in day.

\subsection{Data analysis}

Data from the calculation of population and soil respiration were analyzed descriptively as an average result of three (3) measurements.

\section{Result}

\subsection{Soil analysis}

The presence of microbes in the soil is influenced by physical, chemical and biological soil properties. A biotic factors, including availability of soil nutrient, soil reaction, top soil depth, soil temperature and soil management practices may affect activity of soil microbial communities $[13,14]$. The results of soil analysis showed that the kemenyan rhizosphere stand has very acidic soil pH (3.8-4.1), high to very high $\mathrm{C}$ organic content (4.24-7.00\%), very low to high $P$ availability (1.61-25.05 ppm) and low to moderate cation exchange capacity (14.33-20.75 $\mathrm{cmol} \mathrm{kg}^{-1}$ ) (Table 1$)$.

TABLE 1: Soil chemical properties analysis under kemenyan rhizosphere stand.

\begin{tabular}{l|c|c|c|c|}
\hline Kemenyan species & \multicolumn{5}{|c|}{$\begin{array}{c}\text { Types of analysis } \\
\text { P availability } \\
(\mathrm{ppm})\end{array}$} & $\mathrm{CEC}\left(\mathrm{cmol} \mathrm{kg}^{-1}\right)$ \\
\hline Kemenyan batak & 3.9 & 4.37 & 3.03 & 16.13 \\
\hline Kemenyan bunga & 3.9 & 7.00 & 12.13 & 17.50 \\
\hline Kemenyan minyak & 4.1 & 7.30 & 25.05 & 14.33 \\
\hline Kemenyan durame & 3.8 & 4.24 & 1.61 & 20.75 \\
\hline
\end{tabular}

Acidity $(\mathrm{pH})$ of the soil affects the availability of nutrients and the presence of microbes in the soil. In acid soils, generally fungi are more dominant, whereas, in alkaline soils, bacteria are more dominant. In acid soils, the availability of nutrients is generally lower than that of alkaline soils. Nutrients are higher available at $\mathrm{pH} \mathrm{6-7.} \mathrm{The} \mathrm{presence} \mathrm{of}$ microbes in the soil is also influenced by the availability of nutrients, because microbes 
besides requiring organic matter, microbes also need nutrients for their survival. In the soil, most microbes are heterotrophic which require organic compounds as energy sources and carbon sources [15].

\subsection{Microbial population}

Total microbial population in the soil under kemenyan stand rhizosphere were ranged from $14.2 \times 10^{7} \mathrm{CFU} \mathrm{mL} \mathrm{m}^{-1}$ to $29.1 \times 10^{7} \mathrm{CFU} \mathrm{\textrm {mL } ^ { - 1 }}$ (Table 2). In the kemenyan batak, kemenyan bunga and minyak total fungi population were higher than the total bacteria population, whereas in kemenyan durame total population of bacteria is higher than that of fungi. The highest total microbial population was found in the kemenyan durame rhizosphere area. The occurrence of microbial population differences was caused by the difference in root exudates produced by kemenyan. In addition, population differences were may be caused by differences in nutrient content, differences in soil $\mathrm{pH}$ and also organic matter content. Most of the microbes in the soil are heterotrophic microbes that require organic matter as a carbon source and energy source. The total microbial population consists of microbes that are beneficial or harm to plant growth. According to [16] there is a very close interaction between the diversity of plants with soil microbial diversity, where plants are suspected to be mediators of changes in soil microbial communities that have an impact on ecosystem functions. In the soil, most microbes are heterotroph which requires organic material as an energy source and carbon source. The main source of organic matter comes from plants, so plants play an important role in controlling microbial quality, especially in the rhizosphere. Changes in plant diversity will change the amount, activity and diversity of soil microbes [17]. Plants give effect to the presence of microbes through the supply of carbon produced by root exudates, the number and microbial activity will be greater in the rhizosphere than in non-rhizosphere areas $[18,19]$. Microbial populations may be 10 to 100 -fold higher in the rhizosphere than in soil with no growing plants [19].

TABLE 2: Total population of fungi and total bacteria on the soil under kemenyan stand.

\begin{tabular}{l|c|c|c|}
\hline Kemenyan species & $\begin{array}{c}\text { Total fungi }\left(\times 10^{7}\right. \\
\mathrm{CFU} \mathrm{mL}\end{array}$ & $\begin{array}{c}\text { Total bacteria }\left(\times 10^{7}\right. \\
\left.\mathrm{CFU} \mathrm{\textrm {mL } ^ { - 1 }}\right)\end{array}$ & $\begin{array}{c}\text { Total microbes }(\mathrm{x} \\
\left.10^{7} \mathrm{CFU} \mathrm{mL}^{-1}\right)\end{array}$ \\
\hline Kemenyan batak & 10.3 & 9.9 & 20.2 \\
\hline Kemenyan bunga & 10.9 & 7.0 & 17.9 \\
\hline Kemenyan minyak & 11.0 & 3.2 & 14.2 \\
\hline Kemenyan durame & 13.4 & 15.7 & 29.1 \\
\hline
\end{tabular}


The microbial population of phosphate solubilizing microbes on the soil under kemenyan stands were ranged from $43.2 \times 10^{4} \mathrm{CFU} \mathrm{mL}^{-1}$ to $96.8 \times 10^{4} \mathrm{CFU} \mathrm{mL}^{-1}$. The highest population was found in the kemenyan durame rhizosphere area (Table 3). The presence of phosphate solubilizing microbes increases the availability of phosphorus nutrients by excreting organic acids which are able to chelate $\mathrm{Al}$, Fe and $\mathrm{Ca}$ which bind phosphorus. Phosphate solubilizing microbes population in the soil were ranged from $10^{4}$ to $10^{6} \mathrm{CFU} \mathrm{g}^{-1}$. This value was relatively high, but the effectiveness of phosphate solubilizing depends on the amount and type of organic acids produced. Organic acids such as citric acid and oxalic acid are organic acids which are effective in chelating phosphorus binding elements $[5,15]$.

TABLE 3: Population of phosphate solubilizing microbes on soil under kemenyan stands.

\begin{tabular}{l|c|c|c|}
\hline Kemenyan species & $\begin{array}{c}\text { fungi population } \\
\left(\times 10^{4} \mathrm{CFU} \mathrm{\textrm {mL } ^ { - 1 }}\right)\end{array}$ & $\begin{array}{c}\text { Bacteria } \\
\text { population }\left(\times 10^{4}\right. \\
\left.\text { CFU } \mathrm{mL}^{-1}\right)\end{array}$ & $\begin{array}{c}\text { Total microbes }(\mathrm{x} \\
\left.10^{4} \mathrm{CFU} \mathrm{mL}^{-1}\right)\end{array}$ \\
\hline Kemenyan batak & 40.5 & 44.4 & 84.9 \\
\hline Kemenyan bunga & 20.5 & 22.7 & 43.2 \\
\hline Kemenyan minyak & 22.6 & 30.7 & 53.3 \\
\hline Kemenyan durame & 49.7 & 47.1 & 96.8 \\
\hline
\end{tabular}

Decomposer microbe population were ranged from $26.0 \times 10^{4} \mathrm{CFU} \mathrm{mL}^{-1}$ in kemenyan

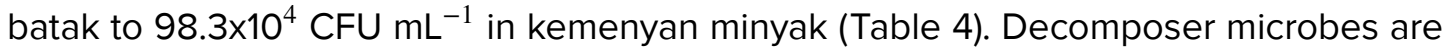
microbes that play a role in the decomposition of organic matter in the soil. Decomposition of organic matter will produce minerals that plants can take as nutrients. Microbial population has positive correlation with decomposition rate, higher microbial population will affect to faster decomposition. Decomposition rate mainly determined by the activity of microbes in a soil, and that activity is determined by microbial biomass and the environmental condition in the soil [19-21].

TABLE 4: Population of decomposer microbes on the soil under the kemenyan stand.

Kemenyan species
Kemenyan batak
Kemenyan bunga
Kemenyan minyak
Kemenyan durame

fungi
population $\left(\times 10^{4}\right.$
CFU $\left.\mathrm{mL}^{-1}\right)$
15.9
15.8
25.1
18.0

\begin{tabular}{|c|c|}
$\begin{array}{c}\text { bacteria population } \\
\left(\times 10^{4} \mathrm{CFU} \mathrm{\textrm {mL } ^ { - 1 } )}\right.\end{array}$ & $\begin{array}{c}\text { Total microbes }(\mathrm{x} \\
\left.10^{4} \mathrm{CFU} \mathrm{g}^{-1}\right)\end{array}$ \\
\hline 10.1 & 26.0 \\
\hline 34.3 & 50.1 \\
\hline 73.2 & 98.3 \\
\hline 20.8 & 38.8 \\
\hline
\end{tabular}

Bacteria and fungi are generally heterotrophic and obtain carbon and energy while degrading organic compounds added to soil including plant residues and dead soil organism. Fungi are an important part of degrading microbe because, like bacteria they 
are dissolved organic matter and responsible for the decomposition of carbon in the biosphere. But fungi, can grow in low moisture areas and in low pH solution [19].

\subsection{Soil respiration}

Respiration is the process of using oxygen and releasing carbon dioxide by microbes. Soil respiration in the kemenyan plant rhizosphere ranged from $1.36 \mathrm{CO}_{2} 100 \mathrm{~g}^{-1}$ day $^{-1}$ (kemenyan batak) to $3.23 \mathrm{CO}_{2} 100 \mathrm{~g}^{-1}$ day $^{-1}$ (kemenyan durame) (Table 5). The highest respiration is found in the soil under kemenyan durame stands. The process of respiration is one measure of microbial activity in the soil. Higher respiration value characterized higher biological activity in the soil. Respiration is related with the content of soil organic matter as a source of microbial energy and the total population of microbes and decomposer microbes [22]. Soil in the kemenyan durame has a high content of organic matter with the highest total microbial population, so that the respiration value is greater than the soil under other kemenyan stands. A major component of respiration is from microbial decomposition of soil organic matter that release $\mathrm{CO}_{2}$. Soil respiration is highly variable and can fluctuate widely depend on substrate availability, organic matter and moisture content [23].

TABLE 5: Respiration of soil in the kemenyan rhizosphere area.

\begin{tabular}{l|c} 
Kemenyan species & Respiration $\left(\mathrm{CO}_{2} 100 \mathrm{~g}^{-1} \mathrm{day}^{-1}\right)$ \\
\hline Kemenyan batak & 1.36 \\
\hline Kemenyan bunga & 2.10 \\
\hline Kemenyan minyak & 2.23 \\
\hline Kemenyan durame & 3.23
\end{tabular}

\section{Discussion}

Soil is a habitat for various types of microbes including bacteria and fungi. Microbes are important in soil biogeochemical processes. Soil microbes participate in the process of oxidation, nitrification, ammonification, nitrogen fixation and other processes that lead to the decomposition of soil organic matter and nutrient transformation [24]. Soil microbes are one indicator of soil fertility. The high population of microbes in the soil, the high fertility of the soil. Fertile soil contain more than one billion microbes [25]. The results showed that the total number of microbes under kemenyan stand (Table 2 ) was classified as moderate with a population range of $14.2 \times 10^{7} \mathrm{CFU} \mathrm{mL} \mathrm{m}^{-1}$ to $29.1 \times 10^{7} \mathrm{CFU}$ $\mathrm{mL}^{-1}$, with the highest yield in the kemenyan durame stand. 
Phosphate solubilizing microbes and organic matter decomposer microbes help in providing nutrients for plant growth. Various types of bacteria and fungi are involved in both of these processes. The population of both types of microbes is very dependent on the content of soil organic matter, because it is a microbial that is heterotrophic. The microbial population of phosphate solubilizing microbes (Table 3) and organic matter decomposer microbes (Table 4) under the kemenyan stand still quite large, which is about $10^{4} \mathrm{CFU} \mathrm{mL}{ }^{-1}$.

Various microbial activities in the soil can be measured one of them is by measuring the amount of oxygen consumed or the amount of carbon dioxide produced by microbial activities in the soil or measuring the process of respiration [26]. The higher the value of respiration produced, the greater the activity of microbes in the soil associated with the availability of nutrients for plant growth. Thus the presence of microbes in the soil will affect plant growth, on the contrary the presence of microbes in the soil is also influenced by the above vegetation associated with the presence of root exudates as a source of energy and carbon sources for the survival of microbes in the soil [27].

\section{Conclusions}

Total microbial population reflects microbial activity in the soil as measured by soil respiration. Higher microbial population under the kemenyan stand rizosphere showed higher microbial activity. The highest microbial activity was found in kemenyan durame rhizosphere.

\section{Acknowledgment}

The authors would like to thank the SEAMEO BIOTROP for their research funds in 2016.

\section{References}

[1] YuX.et al.(2012).Coinoculation with phosphate solubilizing and nitrogen fixing bacteria on sulubilization of rock phosphate and their effect on growth promotion and nutrient uptake by walnut.Euro J.Soil Biol.50,112-117

[2] Burgareli D. et al. (2013). Structure and functions of the bacterial microbiota of plants. Annu. Rev. Plant. Biol. 64, 807-838

[3] MeenaVS.et al.(2017).Plant beneficial rhizospheric microorganism (PBRM) strategies to improve nutrient use efficiency: A review.Ecological Engineering.107,8-32 
[4] VegaNWO.(2007).A review on beneficial effects of rhizosphere bacteria on soil nutrient availability on plant nutrient uptake.Rev.Fac.Nal.Agr.Medellin.60(1),36213643

[5] HouE.et al.(2018).Solubility of phosphorus in subtropical forest soils as influenced by low molecular organic acid and key soil properties.Geoderma.313,172-180

[6] Baliah.et al.(2016).Isolation, identification and characterization on phosphate solubilizing bacteria from different soils of Sri Villiputtur Taluk, Virudhunagar District,Tamil Nadu. Jou Tropical Ecology.57(3),465-474

[7] KhanMS.et al.(2006).Role of phosphate solubilizing microorganism in sustainable agriculture, A review.Agron.Sustain.Dev.27,29-43

[8] ZaidiA.et al.(2009).Plant growth promotion by phosphate solubilizing bacteria.Acta Microbiol.Immunol.Hung.56,263-284

[9] WeiY.et al.(2017).Impact of phosphate solubilizing bacteria inoculation methods on phosphate transformation and longterm utilization in composting Bioresour.Technol.241,134-141

[10] RachmatHH.et al.(2017).Short communication: Strong genetic differentiation of the endemic rosin-producing tree Styrax sumatrana (Styracaceae) in North Sumatra, Indonesia.Biodiversitas,18(4),1331-1335

[11] Land Research Center.(2005). Chemical Analysis of Soil, Plants, Water and Fertilizer. Agricultural Research and Development Center. Agriculture Department

[12] Anasl.(1989).Soil Biology in Practice. Departement of Education and Culture. Bogor Agricultural Institute. Bogor. Indonesia

[13] MohammadAO.(2015). Assesing changes in soil microbial population with some soil physical and chemical properties. International Journal of Plant, Animal and Environmental Sciences 5(3):117-123

[14] FiererN et al.(2003). Variations in microbial community composition through two soil depth profiles. Soil Biology and Biochemistry 35(1):167-176

[15] RaoNS.(2005).Soil microorganism and plant growth (4 ${ }^{\text {th }}$ ed). Oxford and IBH Publishing Co.Pvt.Ltd.New Delhi.India

[16] CarneyKM and PA Matson.(2005).Plant communities, soil microorganism and soil carbon cycling: Does altering the world below ground matter to ecosystem functioning? Ecosystems,8,928-940

[17] HooperDA et al.(2001). Linking above and below-ground biodiversity: Abundance and trophic complexity in soil as a response to experimental plant communities on abandoned arable land.Func.Ecol.15,506-514 
[18] ZhanfengL et al.(2007).Relationship between plant species diversity and soil microbial functional diversity along longitudinal gradient in temperate grasslands of Hulubeir, Inner Mongolia, China. Ecol.Res.10,1172-1179

[19] KennedyAC et al.(2006).Soil microbial community as indicator of soil health.Annals of Arid Zone. 45(3\&4),287-308

[20] BaldrianP.(2017).Microbial activity and the dynamics of ecosystem processes in forest soils. Current Opinion in Microbiology.37,128-134

[21] KorandaM et al.(2013). Seasonal variation in functional properties of microbial communities in beech forest soil. Soil Biology and Biochemistry 60:95-104

[22] ColemanMD et al.(2014).Carbon allocation and nitrogen acquisition in a developing Populous deltoids plantation. Tree Physiology.24,1347-1357

[23] TruuM et al.(2009).Microbial biomass, activity and community composition in constructed wetlands.Sci.Total Environ.407,3958-3971

[24] YanN et al.(2015).Influence of salinity and water content on soil microorganisms. International Soil and Water Conservation Research 3:316-323

[25] PaulEA and FE Clark.(1989).Soil Biology and Biochemistry. Academic Press, Inc. London

[26] HaneyRL et al.(2018).Soil $\mathrm{CO}_{2}$ response to organic and amino acids. Applied Soil Ecology 125:297-300

[27] RyanP et al.(2001).Function and mechanisms of organic anion exudation from plant roots. Annual Review of Plant Biology 52:527-560 